\title{
BAC-based cellular model for screening regulators of BDNF gene transcription
}

\author{
Kaur Jaanson*, Mari Sepp, Tamara Aid-Pavlidis and Tõnis Timmusk
}

\begin{abstract}
Background: Brain derived neurotrophic factor (BDNF) belongs to a family of structurally related proteins called neurotrophins that have been shown to regulate survival and growth of neurons in the developing central and peripheral nervous system and also to take part in synaptic plasticity related processes in adulthood. Since BDNF is associated with several nervous system disorders it would be beneficial to have cellular reporter system for studying its expression regulation.

Methods: Using modified bacterial artificial chromosome (BAC), we generated several transgenic cell lines expressing humanised Renilla luciferase (hRluc)-EGFP fusion reporter gene under the control of rat BDNF gene regulatory sequences (rBDNF-hRluc-EGFP) in HeLa background. To see if the hRluc-EGFP reporter was regulated in response to known regulators of BDNF expression we treated cell lines with substances known to regulate BDNF and also overexpressed transcription factors known to regulate BDNF gene in established cell lines.
\end{abstract}

Results: rBDNF-hRluc-EGFP cell lines had high transgene copy numbers when assayed with qPCR and FISH analysis showed that transgene was maintained episomally in all cell lines. Luciferase activity in transgenic cell lines was induced in response to ionomycin-mediated rise of intracellular calcium levels, treatment with HDAC inhibitors and by over-expression of transcription factors known to increase BDNF expression, indicating that transcription of the transgenic reporter is regulated similarly to the endogenous BDNF gene.

Conclusions: Generated rBDNF-hRluc-EGFP BAC cell lines respond to known modulators of BDNF expression and could be used for screening of compounds/small molecules or transcription factors altering BDNF expression.

Keywords: BDNF, Cell line, Bacterial artificial chromosome, HDAC inhibitor

\section{Background}

Brain derived neurotrophic factor (BDNF), a nerve growth factor family member [1], has been shown to have important roles in the development and functioning of nervous system [2]. During development, BDNF supports survival and differentiation of distinct neuronal subpopulations $[1,3,4]$. In adulthood, BDNF has been shown to have effects in activity-dependent synaptic plasticity including learning and long-term potentiation [5], pain modulation [6], synaptogenesis $[7,8]$ and regulation of metabolism [9].

$B D N F$ gene has complex transcriptional regulation with different untranslated $5^{\prime}$ exons spliced to a common protein coding $3^{\prime}$ exon. Nine different promoters (I-IX) controlling transcription from nine or eleven $5^{\prime}$

\footnotetext{
* Correspondence: kaur.jaanson@ttu.ee

Department of Gene Technology, Tallinn University of Technology, Akadeemia tee 15, 12618 Tallinn, Estonia
}

exons, in rodents or humans respectively, and two different polyadenylation sites give rise to a range of mRNAs [10-12]. BDNF transcription has been shown to be regulated by a multitude of transcription factors (reviewed in [13]), for instance promoter I by cAMP response element binding protein (CREB) [14], upstream stimulatory factors (USF) [14], myocyte enhancer factor 2D (MEF2D) [15], nuclear factor kappa beta (NFKB) [16], basic helixloop-helix (bHLH)-PAS transcription factor neuronal PAS domain protein 4 (NPAS4) and aryl hydrocarbon receptor nuclear translocator 2 (ARNT2) heterodimer (NPAS4ARNT2) $[17,18]$; promoter II by repressor element-1 transcription factor (REST) [19,20]; promoter IV by CREB [21,22], calcium response factor (CaRF) [23], USF-s $[18,24]$, methyl CpG binding protein 2 (MeCP2) [25], NFkB [26], bHLHB2 [27], and NPAS4-ARNT2 heterodimer [17,18], MEF2C [28]; promoter IX by CREB and 
NPAS4-ARNT2 heterodimer [18]. Due to the presence of many promoters and resulting large number of transcripts with the same protein coding sequence but alternating 5' and 3' untranslated regions, BDNF expression is temporally and spatially controlled in different tissues [11,12,29], developmental stages [30] and within different cell compartments [31-33]. Additionally, the BDNF gene locus also encompasses the antisense BDNF gene (BDNFOS) [12,34,35] with a complex splicing and expression pattern. Transcripts of the antisense BDNF gene have been shown to form dsRNA duplexes with $B D N F$ transcripts [12] and regulate BDNF levels [35] in vivo.

Alterations in BDNF expression have been associated with several neurodegenerative disorders. BDNF expression has been shown to be decreased in brains of Alzheimer's [36], Parkinson's [37,38] and Huntington's disease [39] patients. Changes of BDNF levels are accompanied by several other pathologies, like neuropsychiatric disorders, obesity, impairment of learning and memory, neuropathic pain and epileptogenesis [2]. Due to BDNF involvement in nervous system disorders, it has been of great interest to use it as a therapeutic [40]. Unfortunately, direct use of recombinant BDNF protein is problematic due to its low serum half-life, poor penetration across blood brain barrier and low diffusion properties in tissues. Delivery of BDNF into the brain using viral vectors can have problems with vector toxicity, expression dosage and insertional mutagenesis. These problems have promoted screening of drug candidates that could promote expression of endogenous BDNF [41]. HDAC inhibitors are one class of drugs that have been shown to mediate their effect on memory and synaptic plasticity in models of nervous system disorders through increase in BDNF expression [42,43].

Bacterial artificial chromosomes (BACs) are large capacity vectors which are easy to maintain and modify using homologous recombination in E. coli [44]. Due to their large size, BACs can incorporate whole gene genomic loci while at the same time being easier to handle and modify than yeast artificial chromosomes (YACs). BACs have been used to create transgenic mice and cell lines for studying protein function [45], expression regulation [46-48] and for use in high-throughput screening of gene expression modulators [49].

Our group has previously created transgenic mice using BACs containing human [50] or rat [51] BDNF genomic sequences. Transgenes in these mice recapitulated endogenous $B D N F$ expression patterns in different tissues. In the current study, we have generated transgenic cell lines expressing humanised Renilla luciferase (hRluc)EGFP fusion reporter gene under the control of rat $B D N F$ gene regulatory sequences. To this end we used BAC containing rat $B D N F$ gene locus with BDNF protein coding region replaced with the hRluc-EGFP coding sequence. These transgenes maintain transgene episomally in high numbers and express reporter gene at high levels. Reporter gene is induced in response to rise in intracellular calcium levels, treatment with different HDAC inhibitors and overexpression of NPAS4-ARNT2 heterodimer or constitutively active CREB1 (VP16-CREB) that are known to regulate $B D N F$ expression. These transgenic cell lines could be used for screening drug candidates or transcription factors that modulate BDNF expression.

\section{Results}

\section{Generation of rBDNF-hRluc-EGFP HeLa stable cell lines}

HeLa cell line was chosen for generation of rBDNFhRluc-EGFP cell lines because its relatively carefree growth conditions and fast growth are good properties for transgenic cell line. Endogenous human BDNF gene was also expressed in HeLa cell line showing that signaling pathways regulating $B D N F$ expression were active in HeLa cells (see below). The hRluc-EGFP fusion reporter was used because EGFP fluorescence was useful for initial screening and subcloning of transgenic cell lines by fluorescence microscopy and FACS. However for screening of substances or transcription factors regulating $B D N F$ expression, Renilla luciferase luminescence detection is more sensitive and gives less background signal than fluorescence based detection methods [52]. Renilla luciferase also has commercial live cell substrates that allow for repeated measurements of the treated cells making it easier to assay the time dependent effect on the reporter expression while conserving reagents.

rBDNF-hRluc-EGFP BAC construct used for generating cell lines was created using BAC clone that contains rat $B D N F$ locus spanning $13 \mathrm{~kb}$ upstream of the first exon and $144 \mathrm{~kb}$ downstream of the last polyadenylation signal (Figure 1A). BAC clone was modified by homologous recombination to: (i) replace BDNF coding sequence with sequence coding for humanised Renilla luciferase, Ala-Ala-Ala-Thr linker and EGFP fusion protein (Figure $1 \mathrm{~B}$ ) and (ii) replace $C A T$ gene in $\mathrm{BAC}$ vector by neo cassette to confer resistance to G418 for positive selection during cell line generation. The final rBDNFhRluc-EGFP BAC construct was transfected into HeLa cells by nucleofection and G418 was applied for selection.

Following two months of G418 selection, FACS analysis of polyclonal cell population showed that $15 \%$ of cells were positive for EGFP signal. Luciferase signal measured in cell lysate was $10^{4}$ times over the HeLa background signal (data not shown). By FACS assisted cell sorting a number of single cell clones were established displaying varying levels of transgene expression. Six cell lines were chosen for subsequent analysis: 1A4s2, 1A4s3, 2A4, 2B2s, 3E2s and 3G4s.

rBDNF-hRluc-EGFP cell lines express hRluc-EGFP reporter gene In all six cell lines, EGFP signal was detected by fluorescence microscopy in live cells, and hRluc-EGFP fusion protein 


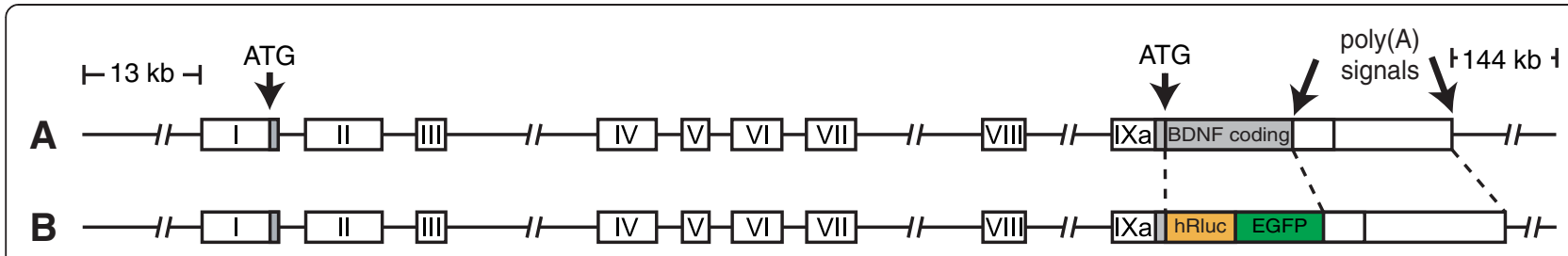

Figure 1 Schematic drawing of the rBDNF-hRluc-EGFP-BAC construct used for generation of HeLa cell-lines expressing the transgene. (A) The BAC used contained the rat BDNF locus spanning $13 \mathrm{~kb}$ upstream of the first exon and $144 \mathrm{~kb}$ downstream of the last polyadenylation signal. The exonic structure of rat BDNF gene is adapted from [11]. (B) The coding region of BDNF was replaced by homologous recombination with sequence coding for humanised Renilla luciferase, Ala-Ala-Ala-Thr linker and EGFP fusion protein. Protein coding regions are shown as gray (BDNF), orange (hRluc) or green (EGFP) boxes. Untranslated regions are shown as white boxes.

was distributed diffusely all over the cell (Figure 2A). Flow-cytometric analysis of the six cell lines showed that the percentage of EGFP positive cells in population varied from 95 to 59 percent (Figure 2B). Additionally there was a variance over several log units in reporter expression level within a cell line (Figure 2C). This prompted us to analyse the stability of reporter expression in time. For this we passaged the cell lines in media containing increasing concentrations of selective antibiotic G418 (0, 200, 400, 800 and $1200 \mu \mathrm{g} / \mathrm{ml}$ ). If no antibiotic was added to the growth medium then the proportion of EGFP positive cells in different cell lines decreased 1.5 to 10 times in three weeks. At the same time the proportion did not change substantially when cells were grown in medium containing 800 or $1200 \mu \mathrm{g} / \mathrm{ml}$ of G418 (data not shown).

Next we measured the activity of Renilla luciferase in live cells using Enduren substrate and normalised it to cellular ATP levels. The signals obtained from the six cell lines were 35 to $\sim 200$ times over the background signal of the parental HeLa cells (Figure 2D). Based on reporter expression level we divided the cell lines into two groups: the group with high reporter expression includes the cell lines $1 \mathrm{~A} 4 \mathrm{~s} 2,1 \mathrm{~A} 4 \mathrm{~s} 3$ and $2 \mathrm{~A} 4$; the low reporter expression group consists of the cell lines $2 \mathrm{~B} 2 \mathrm{~s}, 3 \mathrm{E} 2 \mathrm{~s}$ and $3 \mathrm{G} 4 \mathrm{~s}$. In the first group luciferase signal was $\sim 100-200$ times above background and in the second group around $\sim 35-60$ times above background.

Having detected both, Renilla luciferase luminescence and EGFP fluorescence, of the fusion reporter protein we decided to determine which of the alternative chimaeric rat BDNF hRluc-EGFP mRNAs are transcribed in the six cell lines. Expression of endogenous human $B D N F$ transcripts in the 6 cell lines were similar to parental HeLa cells with a few exceptions: transcript I was not expressed in 3G4s cell line and transcript IXa long (corresponding to transcript IXabcd in [12]) was not expressed in 1A4s2 cell line (Figure 3A). Using RT-PCR analysis we were able to detect transgenic transcripts I, III, IV, V, VI, VIII and IXa in all cell lines (Figure 3B). Transgenic transcript I was expressed at very low levels in five out of six cell lines, its levels were elevated in
2A4 cells. Neither endogenous nor transgenic transcript II was detected in cell lines or parental HeLa cells. While overall expressions of endogenous and transgenic transcripts were similar there were some differences. First, endogenous transcript III was not expressed in any of the cell lines while transgenic transcript III was expressed in all cell lines. Second, transgenic transcript VII was not expressed in any of the cell lines although being expressed endogenously. Altogether these data show that correctly spliced transgenic rat $B D N F$ hRluc-EGFP mRNAs are transcribed and functional hRluc-EGFP fusion protein is expressed in rBDNF-hRluc-EGFP cell lines.

\section{Transgene is maintained in rBDNF-hRluc-EGFP cell lines as} a high copy number episome

Since transgene integration site and copy number can influence reporter gene expression from the transgene, we aimed to determine the copy number and chromosomal state (integrated or episomal) of rBDNF-hRlucEGFP BAC DNA in cell lines. qPCR analysis using copy number standard showed that transgene copy number varied up to five times amongst the different cell lines. Over 900 transgene copies per HeLa genome were present in 1A4s2 and 1A4s3 cell lines and 190-300 transgene copies in 2A4, 2B2s, 3E2s, 3G4s cell lines (Figure 4A). The status of transgene DNA was analysed by fluorescent in situ hybridisation (FISH) with rBDNF-hRluc-EGFP BAC specific probe. As demonstrated in Figure 4B, transgenic BAC DNA was maintained episomally in all cell lines the rBDNF-hRluc-EGFP BAC specific hybridisation signals were localised near chromosomes, but integration was not detected. Transgene copy numbers per cell also varied highly between cells of the same cell line. In conclusion, the obtained rBDNF-hRluc-EGFP cell lines contain relatively high numbers of transgenic BAC DNA per cell that replicates episomally.

\section{Elevated intracellular calcium induces reporter gene expression in rBDNF-hRluc-EGFP cell lines}

$B D N F$ promoters contain several $\mathrm{Ca}^{2+}$ responsive regulatory elements $[14,18,21-24,53]$ and BDNF levels in vivo 


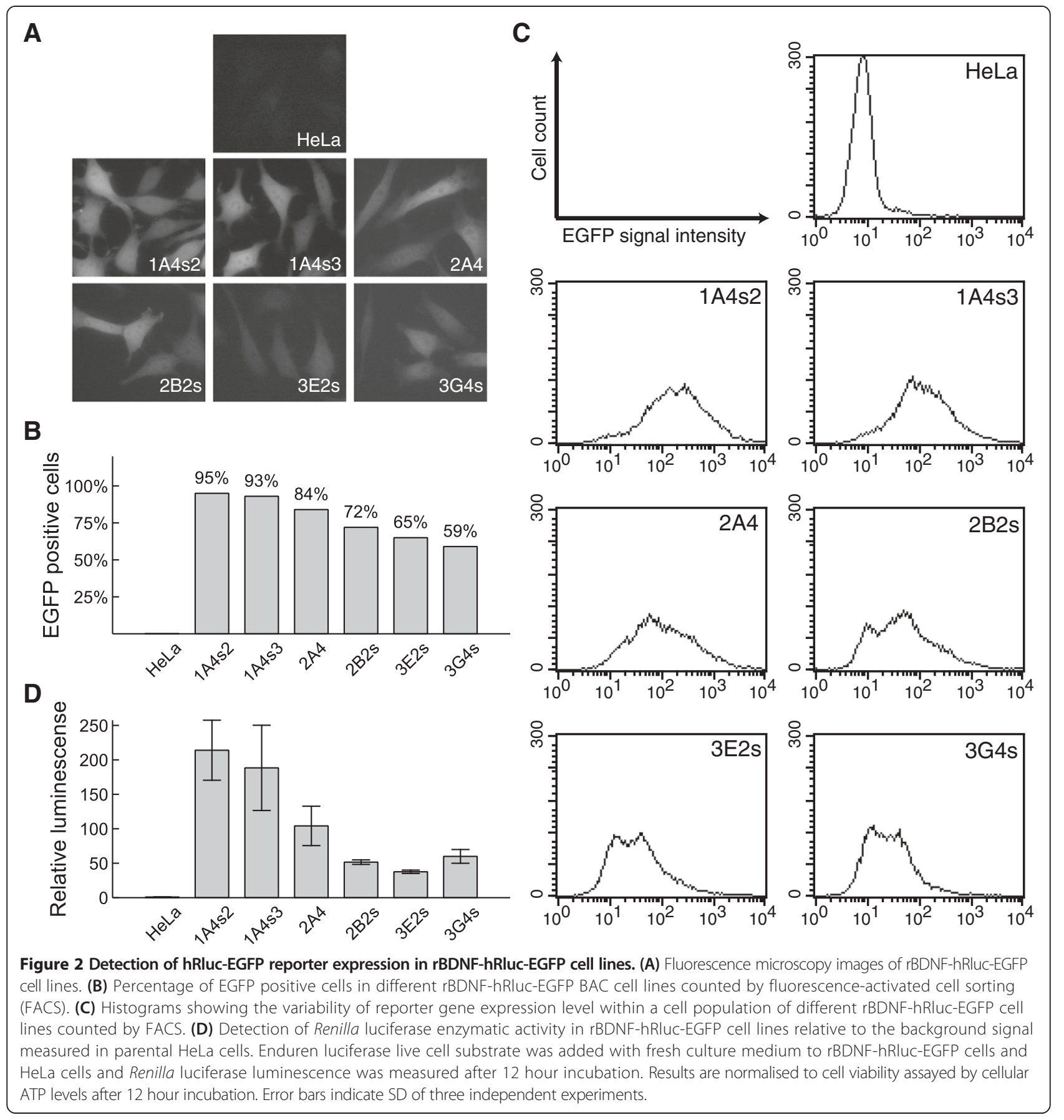

are induced by neural activity related $\mathrm{Ca}^{2+}$ influx into neurons [54]. To test if transgene is induced by elevated intracellular $\mathrm{Ca}^{2+}$ levels in different cell lines we treated cells for 12 hours with $1 \mu \mathrm{M}$ ionomycin, a calcium ionophore known to induce $B D N F$ expression in neurons [55], and monitored Renilla luciferase signal using Enduren live cell luciferase substrate during this period. Ionomycin treatment induced reporter gene expression in all cell lines compared to vehicle treated control. As shown in Figure 5A, the relative increase of luminescence signal was higher in cell lines with low reporter expression: $3 \mathrm{E} 2 \mathrm{~s}, 2 \mathrm{~B} 2 \mathrm{~s}$ and $3 \mathrm{G} 4 \mathrm{~s}$. In these three cell lines the fold change reached its peak after eight hours when it was $2.00(\mathrm{p}<0.01) ; 1.95(\mathrm{p}<0.01)$; and $1.86(\mathrm{p}<0.05)$ respectively. In the cell lines with high reporter expression the fold change remained smaller and the maximum values for cell lines $1 \mathrm{~A} 4 \mathrm{~s} 2,1 \mathrm{~A} 4 \mathrm{~s} 3$ and $2 \mathrm{~A} 4$ were 1.46 $(\mathrm{p}<0.05) ; 1.56(\mathrm{p}<0.01)$ and $1.43(\mathrm{p}<0.01)$ respectively. To exclude the possibility that ionomycin affects cell viability we measured the cell viability levels of 


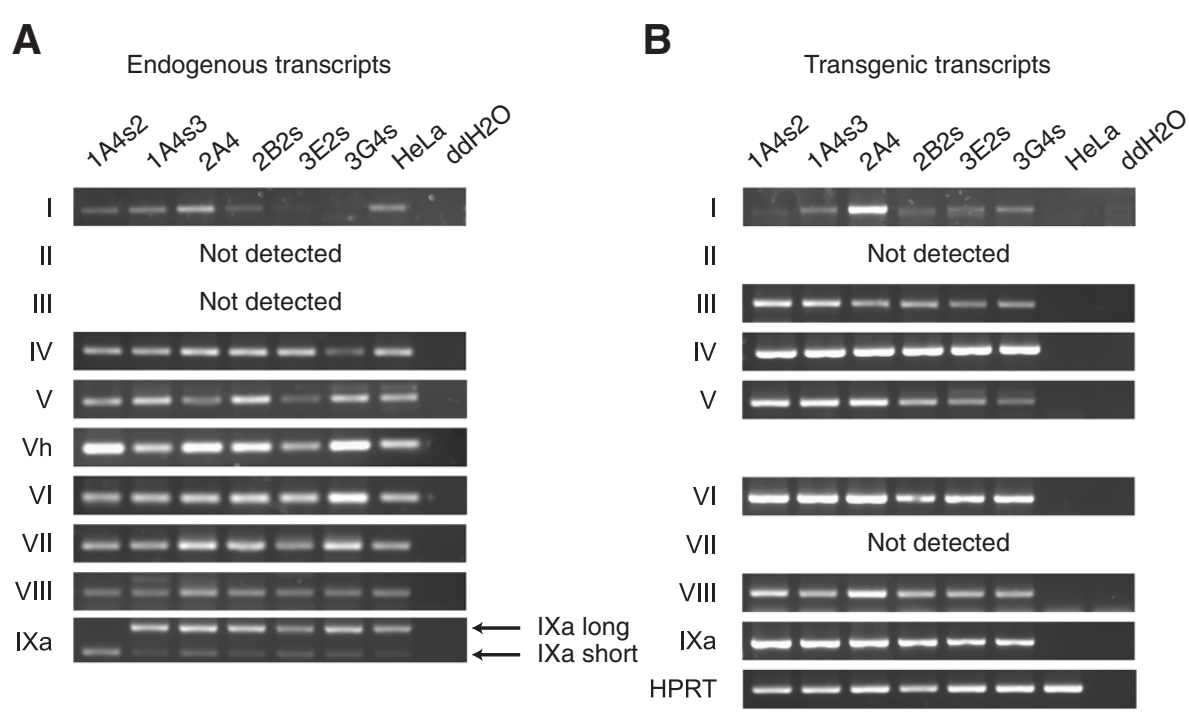

Figure 3 Expression of alternative $5^{\prime}$ exon-specific mRNAs transcribed from rBDNF-hRluc-EGFP cell lines and HeLa cells. Expression of alternatively spliced 5' exon specific transcripts form (A) endogenous BDNF and (B) rBDNF-hRluc-EGFP BAC reporter construct in different rBDNF-hRluc-EGFP cell lines and parental HeLa cells. Endogenous IXa long and short transcripts correspond to human BDNF transcripts IXabcd and IXabd in [12].

control and ionomycin treated cells after 12 hours. No significant decrease in cell viability was detected in response to ionomycin treatment (Figure 5B). These results demonstrate that reporter expression in rBDNF-hRluc-EGFP cell lines is regulated by changes in intracellular calcium level.

\section{HDAC inhibitors induced reporter gene expression in rBDNF-hRluc-EGFP cell lines}

Due to interest in finding low molecular weight substances regulating $B D N F$ expression we sought to establish whether our cell lines could be used for screening of substances modulating $B D N F$ expression. HDAC inhibitors are a class of drugs that inhibit histone deacetylases - group of enzymes that deacetylate histones and non-histone proteins. It has been shown that certain HDAC inhibitors have antidepressant actions and regulate $B D N F$ expression [56], for example valproate [42,57-59], TSA $[58,60]$ and SAHA [61]. Since it would be of interest to use our cell lines for screening of other compounds that could epigenetically regulate $B D N F$ expression, we tested response of the reporter gene in BAC cell lines to four HDAC inhibitors. Two cell lines were chosen for treatments, higher copy number cell line $1 \mathrm{~A} 4 \mathrm{~s} 2$ and lower copy number cell line 3E2s. The cells were treated with $100 \mathrm{nM}$ apicidin, $1 \mu \mathrm{M}$ SAHA, $100 \mathrm{nM}$ TSA and $1 \mathrm{mM}$ sodium valproate for 12 hours while assaying reporter gene expression during that time using Enduren live cell Renilla luciferase substrate.
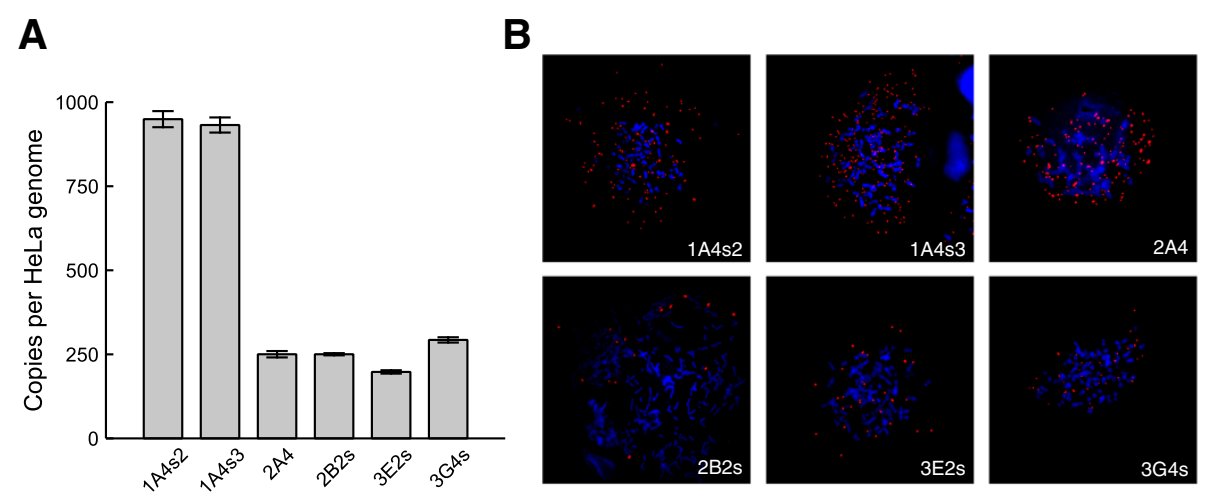

Figure 4 Analysis of transgene copy number and chromosomal state. (A) qPCR analysis of transgene copy number in different rBDNF-hRluc-EGFP cell lines. Error bars show SE of three technical replicates. (B) FISH analysis of reporter construct chromosomal status in different rBDNF-hRluc-EGFP cell lines. Hybridisation was performed with rBDNF-hRluc-EGFP BAC specific probe (red signal) and DNA was stained with Hoecht 33342 (blue signal). 


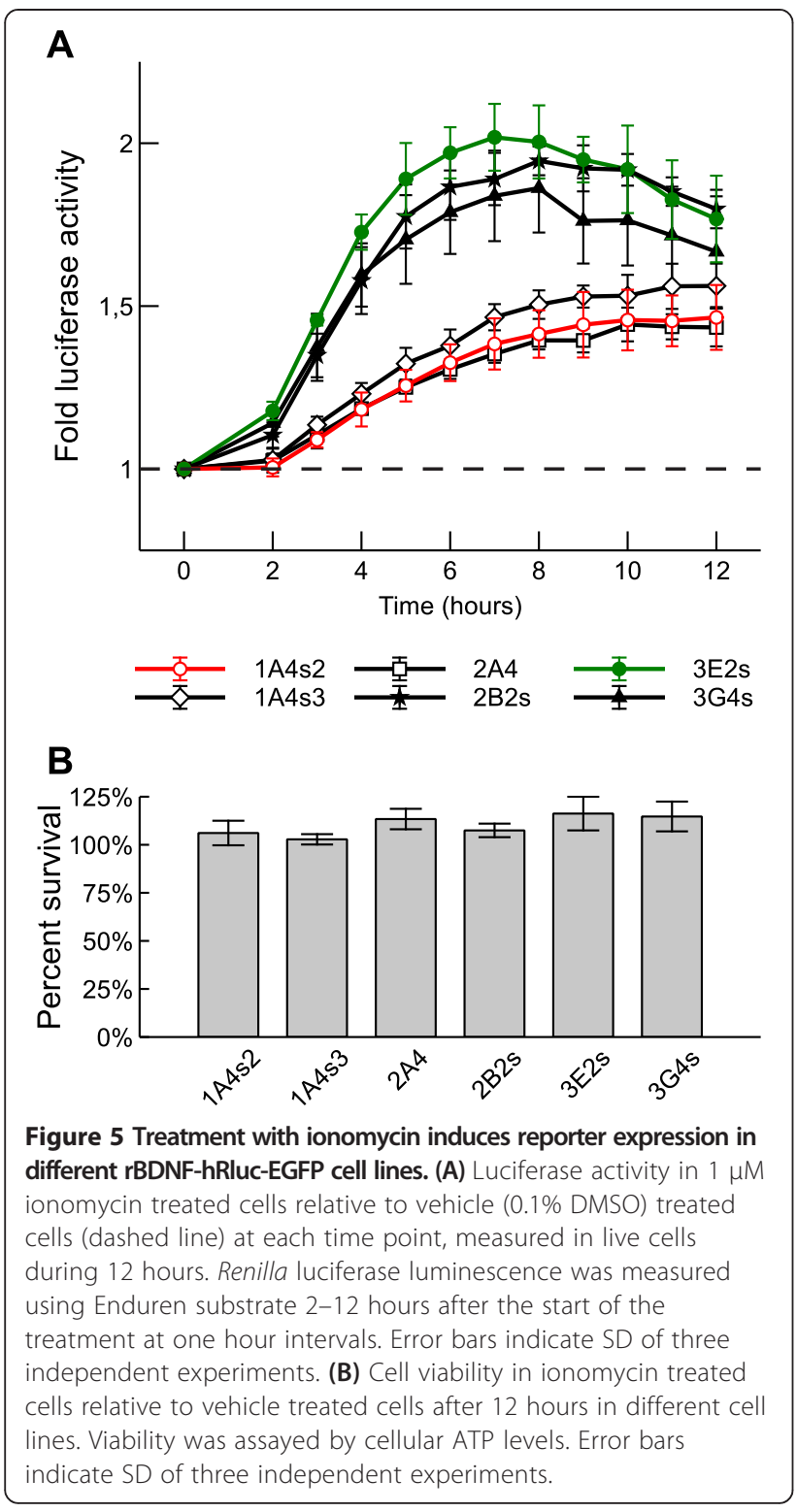

HDAC inhibitors increased reporter gene expression in both cell lines compared to vehicle treated control. $100 \mathrm{nM}$ apicidin increased reporter gene expression in $1 \mathrm{~A} 4 \mathrm{~s} 2$ and 3E2s cell lines 1.70 and 1.58 fold at 12 hours and 11 hours of treatment, respectively (both $\mathrm{p}<0.01$, Figure 6A). $1 \mu \mathrm{M}$ SAHA treatment increased reporter gene expression in $1 \mathrm{~A} 4 \mathrm{~s} 2$ and $3 \mathrm{E} 2 \mathrm{~s}$ cell lines 1.65 and 1.64 fold at 12 hours and 11 hours, respectively (both $p<0.01$ Figure 6B). $100 \mathrm{nM}$ TSA treatment increased reporter gene expression in $1 \mathrm{~A} 4 \mathrm{~s} 2$ and 3E2s cell lines 1.63 and 1.70 fold at 12 hours and 11 hours, respectively (both $\mathrm{p}<0.01$, Figure 6C). $1 \mathrm{mM}$ sodium valproate increased reporter gene expression in $1 \mathrm{~A} 4 \mathrm{~s} 2$ and 3E2s cell lines 1.22 and 1.24 fold at 11 hours and 10 hours, respectively $(\mathrm{p}<0.05$ and $\mathrm{p}<0.01$, Figure 6D). None of the used HDAC inhibitors showed significant effect on cellular survival after
12 hours of treatment in either cell line (Figure 6E and F). Taken together, these results show that HDAC inhibitors upregulate reporter gene expression in rBDNF-hRlucEGFP cell lines $1 \mathrm{~A} 4 \mathrm{~s} 2$ and 3E2s.

VP16-CREB and NPAS4-ARNT2 transcription factors increased transgene expression in $B A C$ transgenic cell lines

$B D N F$ is regulated by 9 different promoters containing binding sites for different transcription factors regulating expression of different $B D N F$ transcripts. Of these transcription factors CREB and bHLH transcription factor heterodimer NPAS4-ARNT2 have been shown to regulate $B D N F$ expression from various promoters $[18,21,22]$. To test if the transgenic cell lines could be used for screening of transcription factors that induce BDNF transcription we transfected cell lines $1 \mathrm{~A} 4 \mathrm{~s} 2$ and 3E2s with constructs expressing VP16-CREB (constitutively active form of CREB1, fused with viral transactivation domain) [62] or NPAS4 and ARNT2, or with empty pRC vector for comparison.

24 hours after transfection VP16-CREB transcription factor increased transgene expression in 1A4s2 and 3E2s cell lines $1.55(\mathrm{p}<0.01)$ fold. Transcription factor NPAS4 together with ARNT2 increased reporter expression in $1 \mathrm{~A} 4 \mathrm{~s} 2$ and 3E2s cell lines $1.89(\mathrm{p}<0.01)$ and 1.35 fold, respectively (Figure 7A and B). These results show that VP16-CREB and NPAS4-ARNT2 heterodimer increase transgene expression in 1A4s2 and 3E2s rBDNF-hRlucEGFP cell lines.

\section{Discussion}

In the current study, we have developed rBDNF-hRlucEGFP reporter cell lines in HeLa background, using bacterial artificial chromosome (BAC) containing rat $B D N F$ genomic locus with protein coding region replaced with hRluc-EGFP fusion reporter gene, for studying the regulation of the $B D N F$ gene and for analysis of the effect of different compounds and transcription factors on $B D N F$ expression. Generation of transgenic mice for studying $B D N F$ regulation using large transgenic constructs by us $[50,51]$ and others [63] has shown that use of BAC (or YAC) transgenic constructs helps to better recapitulate endogenous BDNF expression. It has also been demonstrated that using BAC constructs for generating cell lines helps to avoid transgene integration specific effects and provides levels and timing of transgene expression that mimic that of the endogenous gene [64]. The large rat $B D N F$ genomic locus contained in the BAC construct used in this work should include regulatory elements positioned further away from $B D N F$ gene and help to better emulate endogenous $B D N F$ expression.

Out results show that rBDNF-hRluc-EGFP reporter construct was maintained extrachromosomally in high copy numbers in all established cell lines. Previously it 

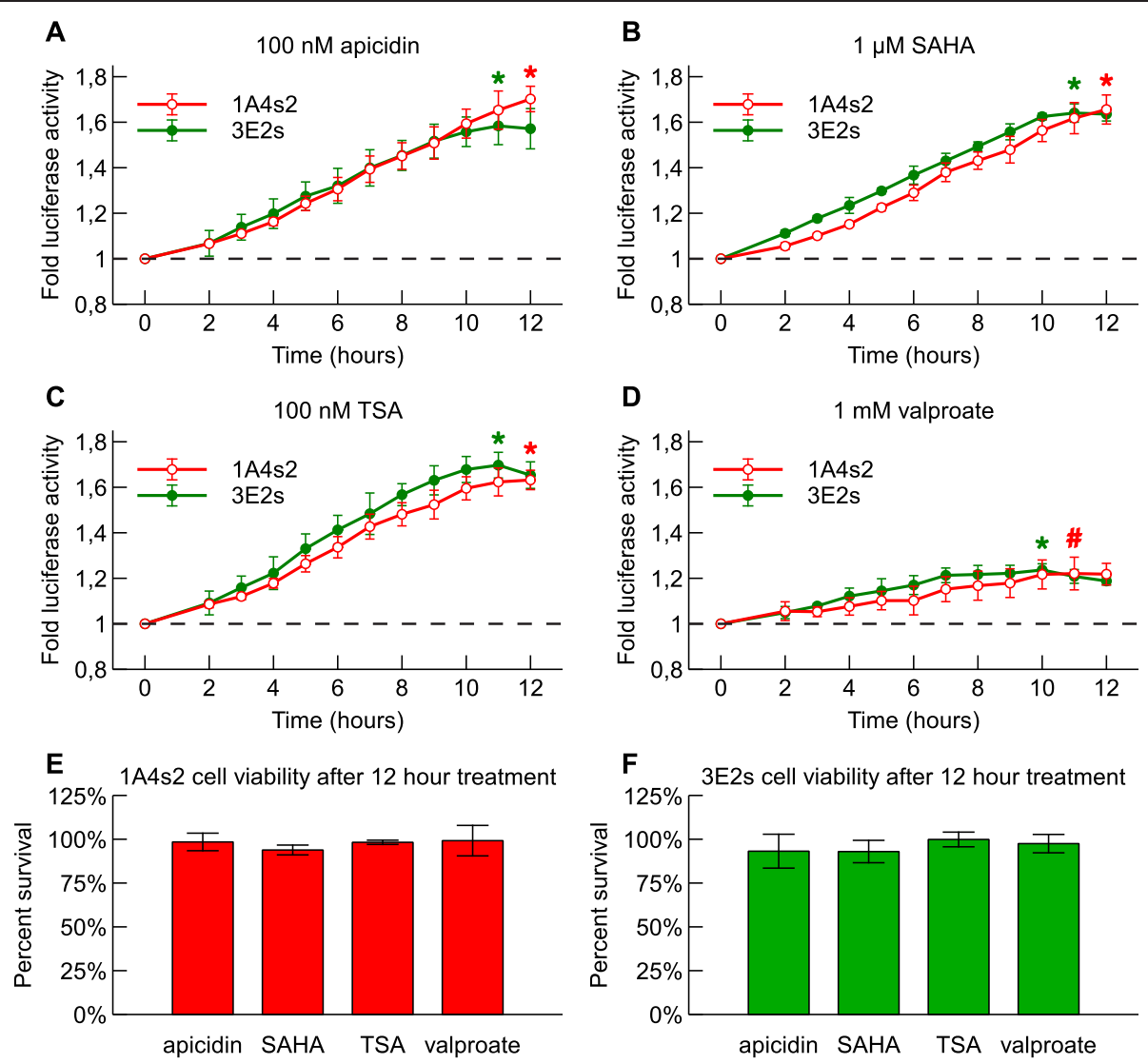

Figure 6 Treatment with HDAC inhibitors induces reporter expression in 1A4s2 and 3E2s rBDNF-hRluc-EGFP cell lines. (A, B, C, D) Fold luciferase activity in HDAC inhibitor treated cells relative to vehicle treated cells (dashed line) measured in live cells during 12 hours. $1 \mathrm{~A} 4 \mathrm{~s} 2$ and 3 E2s cells were treated with HDAC inhibitors apicidin (100 nM) (A), SAHA (1 $\mu \mathrm{M})$ (B), TSA (100 nM) (C), sodium valproate (1 mM) (D) and vehicle control $\left(0.1 \%\right.$ DMSO or water) together with Enduren live cell substrate. Error bars indicate SD of three independent experiments $\left({ }^{*} p<0.01\right.$, \# $p<0.05$, relative to vehicle treated control). (E, F) Cell viability in HDAC inhibitor treated cells relative to vehicle treated cells after 12 hours of treatment in $1 \mathrm{~A} 4 \mathrm{~s} 2$ cell line (E) and 3E2s cell line (F). Viability was assayed by cellular ATP levels. Error bars indicate SD of three independent experiments.

has been shown that plasmids containing matrix attachment regions (MARs) are maintained in double minute extrachromosomal elements in HeLa cells [65]. These are autonomously replicating extrachromosomal elements that are up to a few $\mathrm{Mb}$ in size [66], have been known to be associated with active histones [67] and can be purified by histone immunoprecipitation [68]. MARs and scaffold attachment regions (SARs), together named as S/MARs, are regions on the DNA which attach to nuclear matrix and have been associated with functions such as anchoring of DNA, maintenance of nuclear architecture, regulation of transcription and replication. It has been estimated that S/MARs are spaced on average $70 \mathrm{~kb}$ from each other in mammalian genomes [69]. Given the large size of BDNF locus contained in BAC construct used in this study $(207 \mathrm{~kb})$ it is probable that it contains S/MAR elements enabling extrachromosomal maintenance in HeLa cells. We used SMARTest tool [70] to predict the existence of 6 candidate sites in the genomic locus included in rBDNF-hRluc-EGFP BAC which exhibit
S/MAR like characteristics (data not shown). It would be of interest to study which regions of the BDNF BAC used in this study are responsible for its extrachromosomal maintenance.

We detected expression of almost all $5^{\prime}$ exon-specific BDNF mRNAs in the rBDNF-hRluc-EGFP cell lines showing that the entire $B D N F$ gene is maintained in inserted transgene. We also observed stable and copy number dependent expression of hRluc-EGFP fusion reporter protein by fluorescence and luminescence based methods. Previously it has been shown that protein expression in BAC transgenic cell lines is proportional to transgene copy numbers [71]. BAC-derived BDNF gene is not highly expressed, as shown by transgenic animals previously produced in our lab where one or two copies of transgenic BDNF BAC construct were inserted in the genome. In contrast, the high copy numbers of transgene in the cell lines developed in this study directed high levels of reporter gene expression.

We used hRluc-EGFP fusion protein, analogous to the Rluc-GFP reporter used previously by [72], as a reporter 


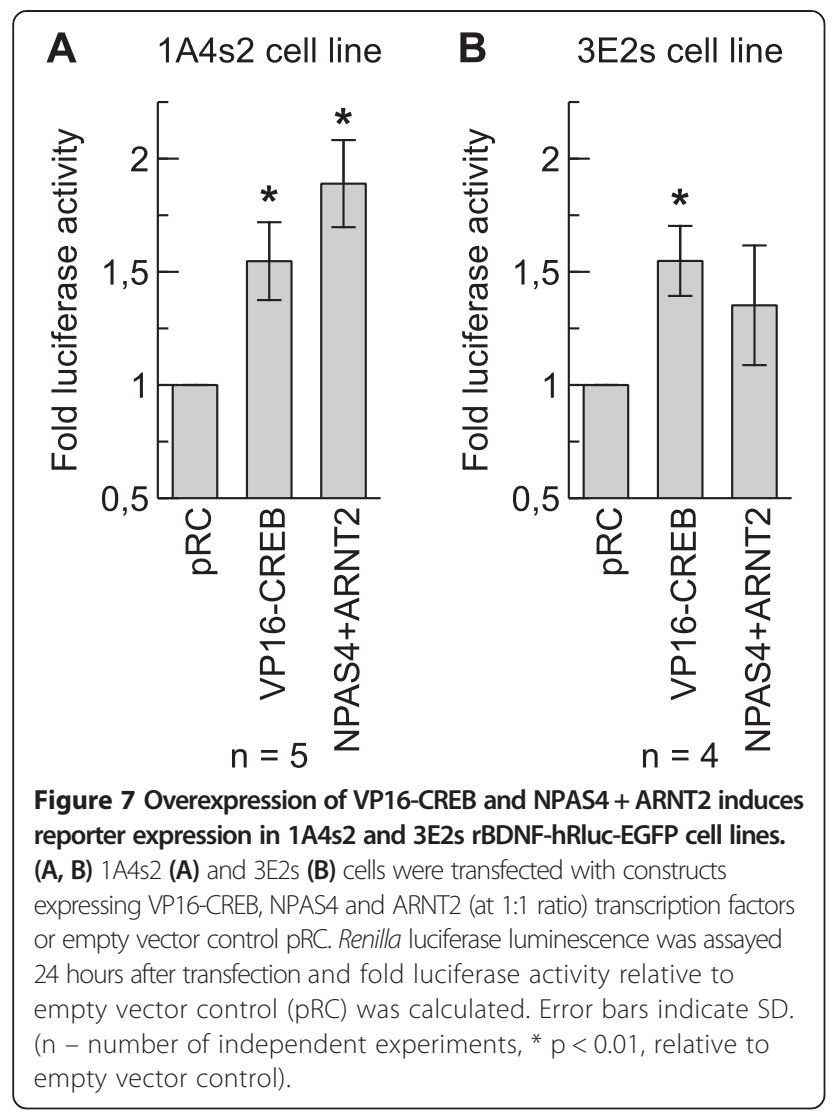

in the BAC construct. The use of hRluc-EGFP protein makes it possible to apply both fluorescence and more sensitive luminescence based methods for reporter detection. While EGFP fluorescence could be used for measuring reporter expression via flow cytometry, use of live cell substrates allow for sensitive detection of Renilla luciferase signal which could be advantageous for highthroughput screening procedures. The half-life of Renilla luciferase is 3-4 hours and the half-life of EGFP is about 26 hours [73] in mammalian cells. However, stability of the hRluc-EGFP fusion protein is not known. It is probable that the induction of measurable reporter activity in response to different treatments underestimates the true effect on transcriptional activity due to slow turnover of the hRluc-EGFP fusion protein, suggesting that it would be important to develop a less stable hRluc-EGFP fusion protein in future studies.

To assess the suitability of the cell lines generated by us for use in studying $B D N F$ gene regulation, the cells were treated with stimuli known to induce $B D N F$ expression. Ionomycin induces $B D N F$ expression through $\mathrm{Ca}^{2+}$ mediated signalling pathways [54], HDAC inhibitors through increasing histone acetylation leading to transcriptionally active chromatin around subset of genes, including BDNF [56,74]. Transcription factor CREB and NPAS4-ARNT2 heterodimer have been shown to promote transcription from several $B D N F$ promoters $[18,21,22]$. As expected, treatment with different modulators of $B D N F$ expression induced expression of hRluc-EGFP fusion reporter protein. The effect of treatment with ionomycin or HDAC inhibitors was different when comparing high and low transgene copy number cell lines. Ionomycin induced reporter expression to a higher extent in lower copy number cell lines than in higher copy number cell lines. However, treatment of high and low transgene copy number cell lines with different HDAC inhibitors induced transgene expression similarly in both cell lines regardless of the used inhibitor. The apparent copy number dependent effect on reporter induction by ionomycin might be explained by higher number of transcription factor response elements in high copy number cell lines competing for limited supply of $\mathrm{Ca}^{2+}$ dependent transcription factors. In contrast, the effect of HDAC inhibitors on gene expression is more general, regulating expression of large number of genes, and they may act by inducing transgene expression independent of copy number.

Since BDNF has been primarily studied as a neuronal gene, the non-neuronal nature of the generated transgenic cell lines sets certain limitations to their use in studying neuron-specific regulation of BDNF expression. For example, BDNF mRNAs have been known to be transported to dendrites [75,76] and their translation there to be regulated in response to local synaptic signalling [77], regulatory steps that are not recapitulated in our cell lines. Also, neuronal stimuli known to regulate BDNF expression, for example depolarisation by potassium [54] or glutamate [78], do not recapitulate in HeLa background. Therefore, modulators that have been found to regulate transgene expression in these transgenic cell lines should be also verified in neuronal background. However, the active transcription of endogenous BDNF mRNAs in HeLa cells and the robust nature of the HeLa cells make these cell lines convenient tools for screening of factors regulating BDNF expression.

\section{Conclusions}

In conclusion, we have generated a rBDNF-hRluc-EGFP BAC cellular reporter model for use in studying $B D N F$ regulation. Transgene is maintained in cell lines extrachromosomally as high copy number episome. High transgene copy number makes it possible to reliably detect reporter expression. Transgene expression is induced in response to known modulators of $B D N F$ expression making these cell lines useful for further studies of $B D N F$ regulation.

\section{Methods}

Constructs

BAC clone CH230-106 M15 containing rat BDNF gene was purchased from Chori BACPAC Resources. Clone 
CH230-106 M15 contains rat genomic DNA region spanning the BDNF gene locus cloned into the EcoRI site of pTARBAC2.1 vector. The vector carried chloramphenicol resistance and resided in $E$. coli host strain $\mathrm{DH} 10 \mathrm{~B}\left(\mathrm{recA}^{-}\right.$, recBC ${ }^{+}$). Sequence of the BAC clone $\mathrm{CH} 230-106$ M15 was obtained from NCBI GeneBank [GenBank:AC108236]. Vectors pCDNA3.1-NPAS4, pCDNA3.1-ARNT2 and pACTCREB1 (containing VP16 viral transcription activation domain) have been described previously [18].

\section{Homologous recombination}

BAC modifications using Red/ET homologous recombination were performed according to the BAC Modification Counter-Selection System protocol (Gene Bridges $\mathrm{GmbH})$. For amplification of inserts, 75-mer oligonucleotides were synthesised (Proligo). The 5 '-end of each oligonucleotide contained 50 nucleotides of homology region shared by the target $\mathrm{BAC}$ and a linear insert followed by a 25 nucleotide primer for PCR amplification of the linear insert from the template. Where necessary, linker sequence was added between homology arm and primer sequences. Inserts for homologous recombination were amplified by PCR using Expand Long Template PCR system (Roche) or Hot GyroPol PCR system (Solis BioDyne). The synthetic humanised version of Renilla luciferase reporter gene (hRluc), the red-shifted variant of wild-type Aequorea green fluorescent protein (EGFP) reporter gene and SV40-Neo ${ }^{\mathrm{r}}$-polyA cassette were amplified from pTK-hRluc (Promega), pEGFP-N1 (Clontech) and pEGFP-C1 vectors (Clontech), respectively. Following PCR primers were used for insert synthesis - hRLuc: sense 5'-CCT GTT CTG TGT CTG TCT CTG CTC CTT CCC ACA GTT CCA CCA GGT GAG AAG AGT GAT GGC TTC CAA GGT GTA CGA CCC CG-3', antisense 5'-ATA CAA ATA GAT AAT TTT TGT CTC AAT ATA ATC TAT ACA ACA TAA ATC CAT TAC TGC TCG TTC TTC AGC ACG CGC T-3'; EGFP: sense 5' -TGG GTA AGT ACA TCA AGA GCT TCG TGG AGC GCG TGC TGA AGA ACG AGC AGG CCG CCG CCG CCA CCA TGG TGA GCA AGG GCG AGG AGC TG-3', antisense 5'-ATA CAA ATA GAT AAT TTT TGT CTC AAT ATA ATC TAT ACA ACA TAA ATC CAT TAC TTG TAC AGC TCG TCC ATG CCG A-3'; SV40- Neo $^{\text {r }}$-polyA cassette: sense 5'-CAC CAT AAT GAA ATA AGA TCA CTA CCG GGC GTA TTT TTT GAG TTA TCG AGA TTT TCA GGA GCT AAG GAA GCT AAA TTC AAA TAT GTA TCC GCT CAT GAG A-3', antisense 5'-ATT CAT CCG CTT ATT ATC ACT TAT TCA GGC GTA GCA ACC AGG CGT TTA AGG GCA CCA ATA ACT GCC TTT TTT ATT CTG TCT TTT TAT TGC CGT C-3'. $\mathrm{BAC}$ was modified by first replacing BDNF protein coding region with hRluc coding sequence, then inserting AlaAla-Ala-Thr linker and EGFP coding sequences to the end of hRluc sequence and finally by replacing the CAT gene in BAC vector with SV40-Neo ${ }^{r}$-polyA cassette. The modified BAC containing colonies were screened by colony PCR and colony hybridisation and further verified by restriction analysis and sequencing.

\section{Cell culture and transfection}

HeLa (DSMZ) human cervical cancer cells were propagated in DMEM (Dulbecco's Modified Eagle Medium; PAA) supplemented with $10 \%$ fetal bovine serum (PAA), penicillin (PAA) and streptomycin (PAA) at $37^{\circ} \mathrm{C}$ in $5 \%$ CO2. For BAC DNA transfection $1 \mu \mathrm{g}$ of BAC DNA purified with Large-Construct Kit (Qiagen) was mixed with $5 \times 10^{6}$ HeLa cells and transfection was performed using Amaxa Nucleofector program A-28 and Cell Line Nucleofector Kit R (Amaxa). 72 hours later $400 \mu \mathrm{g} /$ $\mathrm{ml}$ G418 (Sigma) was added to the growth medium to select for BAC containing cells. After two months of selection, single EGFP-positive clones were isolated with FACSAria cell sorting system (Becton-Dickinson). The cell lines were routinely grown in medium containing $800 \mu \mathrm{g} / \mathrm{ml} \mathrm{G418}$. For transfection of plasmid constructs cells were seeded into white 96-well clear bottom microtiter plate (Greiner Bio-One) at 10000 cells per well in a volume of $200 \mu \mathrm{l}$ of G418-containing culture medium. The next day medium was replaced with $100 \mu \mathrm{l}$ of medium without G418 and cells were transfected with GenJet Hela transfection reagent (SignaGen Laboratories) using $100 \mathrm{ng}$ of DNA per well at 1:3 DNA to lipid ratio. NPAS4 and ARNT2 constructs were cotransfected at 1:1 ratio. Five hours post-transfection medium was replaced with $200 \mu \mathrm{l}$ of G418-containing medium.

\section{Drug treatments}

One day before treatments, cells were seeded into white 96-well clear bottom microtiter plates (Greiner Bio-One) at 10000 cells per well. The next day medium was replaced with $75 \mu \mathrm{l}$ of fresh medium containing ionomycin, apicidin, sodium valproate (all Sigma Aldrich), SAHA or TSA (both Cayman Chemical). All drugs except sodium valproate were dissolved in DMSO and added to cells at a final DMSO concentration of $0.1 \%$. Sodium valproate was dissolved in MilliQ grade water. Appropriate vehicle controls (DMSO or water) were included in all experiments.

\section{Reporter assays}

EGFP was detected by fluorescence microscopy (Axiovert $200 \mathrm{M}$, Zeiss) and flow cytometry (FACSCalibur, BectonDickinson). In flow-cytometric analysis no compensation was used and markers for positive EGFP-signals were set on FL1 vs FL2 dot blot using the autofluorescence diagonal of parental HeLa cells. EGFP-positive cells were identified by divergence from the autofluorescence diagonal towards higher FL1 fluorescence. For monitoring hRluc 
enzymatic activity in live cells, $30 \mu \mathrm{M}$ Enduren substrate (Promega) was added to cells at the beginning of drug treatment and luminescence was measured once per hour at 2-12 hour time points. For measuring endpoint hRluc activity, cells were lysed in $20 \mu$ Passive Lysis Buffer (Promega) 24 hours after transfection and subjected to Renilla-Glo Luciferase Assay System (Promega) according to the manufacturer's instructions. Relative luminescence was measured with GENios Pro plate reader (TECAN). For normalisation and monitoring cell viability ViaLight Plus Cell Proliferation And Cytotoxicity BioAssay Kit (Lonza, USA) were used. For drug treatments, three independent experiments were performed, each in triplicate. Luciferase signal in response to drug treatments was normalised to vehicle control for each time point, means and standard deviations were calculated and $\mathrm{t}$-tests for analysis of statistical significance for indicated time points were performed. For transcription factor transfections, four or five independent experiments were performed, each in triplicate. Luciferase signal in response to expression of transcription factor(s) was normalised to signal in $\mathrm{pRC}$ empty vector transfected cells, means and standard deviations were calculated and t-tests for analysis of statistical significance were performed.

\section{Fluorescence in situ hybridisation}

Mitotic blocking was performed by treating cells with $50 \mathrm{ng} / \mathrm{ml}$ colcemid (Sigma) for 4 hours. The cells were harvested by shakeoff and subjected to hypotonic treatment with $0.075 \mathrm{M} \mathrm{KCl}$ for $15 \mathrm{~min}$. The cells were fixed in methanol:acetic acid (3:1) and used for chromosome slide preparation. Slides were chemically aged and denatured as described [79]. Prior to denaturation and hybridisation, chromosome preparations were treated with RNase A $(100 \mu \mathrm{g} / \mathrm{ml}$ in $2 \times \mathrm{SSC})$, pepsin $(50 \mu \mathrm{g} / \mathrm{ml}$ in $0.01 \mathrm{~N} \mathrm{HCl}$ ) and $1 \%$ formaldehyde (in PBS containing $50 \mathrm{mM} \mathrm{MgCl}$ ). rBDNF-hRluc-EGFP BAC specific probe was labeled with digoxigenin-11-dUTP (Roche) by nick translation. For each hybridisation $45 \mathrm{ng}$ of the labeled probe was used together with $25 \mu \mathrm{g}$ of salmon sperm DNA. Hybridisation was carried out by incubating slides in $50 \%$ deionised formamide, $2 \times \mathrm{SSC}, 0.1 \mathrm{M}$ phosphate buffer, $10 \%$ dextran sulfate overnight at $37^{\circ} \mathrm{C}$ in humid chamber. Hybridised probe was detected by affinity reaction with mouse anti-digoxygenin primary antibody (Roche) followed by Alexa 546 conjugated anti-mouse secondary antibody (Life Technologies, USA) and chromosomes were counterstained with Hoecht 33342. Slides were mounted in ProLong Gold anti-fade reagent (Life Technologies, USA) and imaged with Zeiss LSM DUO microscope.

\section{RNA extraction and RT-PCR}

Total RNA from cells was purified with RNeasy Micro kit (Quiagen) as recommended by the manufacturer and treated with DNase I using DNA-free kit (Ambion). First-strand cDNA was synthesised from $5 \mu \mathrm{g}$ of total RNA with Superscript III reverse transcriptase (Life Sciences) according to manufacturer's recommendations. PCR reactions were performed with HotFire polymerase (Solis Biodyne) in a volume of $10 \mu \mathrm{l}$ containing 1/80 of reverse transcription reaction as a template. Human $B D N F 5^{\prime}$ exons' specific primers have been described previously [12]. Rat BDNF $5^{\prime}$ exons' specific primers have been described previously [11] and were used in combination with $h R l u c$ specific antisense primer $5^{\prime}$-GTA CTT GTA GTG ATC CAG GAG GCG AT-3'.

\section{Genomic DNA extraction and quantitative PCR}

Genomic DNA was extracted from cells by proteinase K digestion and phenol:chloroform extraction followed by ethanol precipitation and resuspension overnight in TE (pH 8.0). Genomic DNA concentration was quantified with UV spectrophotometer (NanoDrop) and diluted to $16 \mathrm{ng} / \mu \mathrm{l}$ for qPCR. For standard curve, a series of mixtures in which the number of pEGFP-C1 (Promega) plasmid molecules ranged from 128 to 1024 copies per HeLa genome were prepared using HeLa genomic DNA. 32 ng of genomic DNA from different cell lines or copy number standards were subjected to quantitative PCR. Quantitative PCR was performed on Roche LightCycler 2.0 using qPCR Core kit for $\mathrm{SYBR}^{\circ}$ Green I No ROX (Eurogentec). qPCR reactions with copy number standards were performed in duplicate. qPCR reactions with cell line genomic DNAs were performed in triplicate. Melting curve analysis was carried out at the end of cycling to confirm amplification of a single PCR product. Following EGFP and human TRKB (genomic control) specific PCR primer sets were used: EGFP sense 5' - CAG AAG AAC GGC ATC AAG GTG-3', antisense 5' - TGG GTG CTC AGG TAG TGG TTG -3'; TRKB sense 5' - CAC AGG GCT CCT TAA GGA TAA C -3', antisense 5'- GCA CAG TGA GGT TGA CAG AAT C-3'. Copy number estimates were calculated with qBASEPlus 2.6 software (Biogazelle) using EGFP as target and TRKB as reference.

\section{Abbreviations}

BAC: Bacterial artificial chromosome; BDNF: Brain derived neurotrophic factor; FISH: Fluorescence in situ hybridisation; HDAC: Histone deacetylase; hRluc: Humanised Renilla luciferase; MAR: Matrix attachment region; SAR: Scaffold attachment region; YAC: Yeast artificial chromosome.

\section{Competing interests}

The authors declare that they have no competing interests.

\section{Authors' contributions}

$\mathrm{KJ}$ performed reporter expression analysis, QPCR analysis of transgene copy number, fluorescent in situ hybridisation, drug treatments, transcription factor transfection, data analysis of the results and drafting of the manuscript. MS carried out BAC transfection, established cell lines, performed FACS sorting and analysis, fluorescence microscopy, ionomycin treatments and contributed to the initial design of the study. TAP prepared the 
rBDNF-hRluc-EGFP BAC construct and contributed to the initial design of the study. TT conceived and coordinated the study. All authors contributed to the preparation of the manuscript. All authors read and approved the final manuscript

\section{Acknowledgements}

This work was supported by Estonian Ministry of Education and Research (targeted funding grant 0140143, Institutional Research funding IUT 19-18), Estonian Science Foundation (Grant 8844), Enterprise Estonia (Grant EU27553) and Estonian Academy of Sciences. We thank Indrek Koppel for advice and Epp Väli and Maila Rähn for technical assistance.

Received: 30 April 2014 Accepted: 13 June 2014

Published: 18 June 2014

\section{References}

1. Barde YA, Edgar D, Thoenen $\mathrm{H}$ : Purification of a new neurotrophic factor from mammalian brain. EMBO J 1982, 1:549-553.

2. Binder DK, Scharfman HE: Brain-derived neurotrophic factor. Growth Factors Chur Switz 2004, 22:123-131.

3. Jones KR, Fariñas I, Backus C, Reichardt LF: Targeted disruption of the BDNF gene perturbs brain and sensory neuron development but not motor neuron development. Cell 1994, 76:989-999.

4. Ernfors $P$, Lee KF, Jaenisch R: Mice lacking brain-derived neurotrophic factor develop with sensory deficits. Nature 1994, 368:147-150.

5. Lu Y, Christian K, Lu B: BDNF: a key regulator for protein synthesis-dependent LTP and long-term memory? Neurobiol Learn Mem 2008, 89:312-323.

6. Pezet S, McMahon SB: Neurotrophins: mediators and modulators of pain. Annu Rev Neurosci 2006, 29:507-538.

7. Alsina B, Vu T, Cohen-Cory S: Visualizing synapse formation in arborizing optic axons in vivo: dynamics and modulation by BDNF. Nat Neurosci 2001, 4:1093-1101.

8. Sairanen M, Lucas G, Ernfors P, Castrén M, Castrén E: Brain-derived neurotrophic factor and antidepressant drugs have different but coordinated effects on neuronal turnover, proliferation, and survival in the adult dentate gyrus. J Neurosci Off J Soc Neurosci 2005, 25:1089-1094.

9. Rios M: BDNF and the central control of feeding: accidental bystander or essential player? Trends Neurosci 2013, 36:83-90.

10. Timmusk T, Palm K, Metsis M, Reintam T, Paalme V, Saarma M, Persson H: Multiple promoters direct tissue-specific expression of the rat BDNF gene. Neuron 1993, 10:475-489

11. Aid T, Kazantseva A, Piirsoo M, Palm K, Timmusk T: Mouse and rat BDNF gene structure and expression revisited. J Neurosci Res 2007, 85:525-535.

12. Pruunsild P, Kazantseva A, Aid T, Palm K, Timmusk T: Dissecting the human BDNF locus: bidirectional transcription, complex splicing, and multiple promoters. Genomics 2007, 90:397-406.

13. West AE, Pruunsild P, Timmusk T: Neurotrophins: transcription and translation. Handb Exp Pharmacol 2014, 220:67-100.

14. Tabuchi A, Sakaya H, Kisukeda T, Fushiki H, Tsuda M: Involvement of an upstream stimulatory factor as well as CAMP-responsive element-binding protein in the activation of brain-derived neurotrophic factor gene promoter I. J Biol Chem 2002, 277:35920-35931.

15. Flavell SW, Kim T-K, Gray JM, Harmin DA, Hemberg M, Hong EJ, Markenscoff-Papadimitriou E, Bear DM, Greenberg ME: Genome-wide analysis of MEF2 transcriptional program reveals synaptic target genes and neuronal activity-dependent polyadenylation site selection. Neuron 2008, 60:1022-1038.

16. Lubin FD, Ren $Y, X u X$, Anderson AE: Nuclear factor-kappa B regulates seizure threshold and gene transcription following convulsant stimulation. J Neurochem 2007, 103:1381-1395.

17. Lin Y, Bloodgood BL, Hauser JL, Lapan AD, Koon AC, Kim T-K, Hu LS, Malik AN, Greenberg ME: Activity-dependent regulation of inhibitory synapse development by Npas4. Nature 2008, 455:1198-1204.

18. Pruunsild P, Sepp M, Orav E, Koppel I, Timmusk T: Identification of cis-elements and transcription factors regulating neuronal activity-dependent transcription of human BDNF gene. J Neurosci Off J Soc Neurosci 2011, 31:3295-3308.

19. Timmusk T, Palm K, Lendahl U, Metsis M: Brain-derived neurotrophic factor expression in vivo is under the control of neuron-restrictive silencer element. J Biol Chem 1999, 274:1078-1084.

20. Zuccato C, Tartari M, Crotti A, Goffredo D, Valenza M, Conti L, Cataudella T, Leavitt BR, Hayden MR, Timmusk T, Rigamonti D, Cattaneo E: Huntingtin interacts with REST/NRSF to modulate the transcription of NRSE-controlled neuronal genes. Nat Genet 2003, 35:76-83.

21. Shieh PB, Hu SC, Bobb K, Timmusk T, Ghosh A: Identification of a signaling pathway involved in calcium regulation of BDNF expression. Neuron 1998, 20:727-740.

22. Tao X, Finkbeiner S, Arnold DB, Shaywitz AJ, Greenberg ME: Ca2+ influx regulates BDNF transcription by a CREB family transcription factor-dependent mechanism. Neuron 1998, 20:709-726.

23. Tao X, West AE, Chen WG, Corfas G, Greenberg ME: A calcium-responsive transcription factor, $\mathrm{CaRF}$, that regulates neuronal activity-dependent expression of BDNF. Neuron 2002, 33:383-395.

24. Chen WG, West AE, Tao X, Corfas G, Szentirmay MN, Sawadogo M, Vinson C, Greenberg ME: Upstream stimulatory factors are mediators of $\mathrm{Ca} 2+$-responsive transcription in neurons. J Neurosci Off J Soc Neurosci 2003, 23:2572-2581.

25. Martinowich $K$, Hattori D, Wu H, Fouse $S$, He F, Hu Y, Fan G, Sun YE: DNA methylation-related chromatin remodeling in activity-dependent BDNF gene regulation. Science 2003, 302:890-893.

26. Lipsky RH, Xu K, Zhu D, Kelly C, Terhakopian A, Novelli A, Marini AM: Nuclear factor kappaB is a critical determinant in N-methyl-D-aspartate receptor-mediated neuroprotection. J Neurochem 2001, 78:254-264.

27. Jiang X, Tian F, Du Y, Copeland NG, Jenkins NA, Tessarollo L, Wu X, Pan H, Hu X-Z, Xu K, Kenney H, Egan SE, Turley H, Harris AL, Marini AM, Lipsky RH: BHLHB2 controls Bdnf promoter 4 activity and neuronal excitability. J Neurosci Off J Soc Neurosci 2008, 28:1118-1130.

28. Lyons MR, Schwarz CM, West AE: Members of the myocyte enhancer factor 2 transcription factor family differentially regulate Bdnf transcription in response to neuronal depolarization. J Neurosci 2012, 32:12780-12785.

29. Timmusk T, Persson H, Metsis M: Analysis of transcriptional initiation and translatability of brain-derived neurotrophic factor mRNAs in the rat brain. Neurosci Lett 1994, 177:27-31.

30. Timmusk T, Belluardo N, Persson H, Metsis M: Developmental regulation of brain-derived neurotrophic factor messenger RNAs transcribed from different promoters in the rat brain. Neuroscience 1994, 60:287-291.

31. Pattabiraman PP, Tropea D, Chiaruttini C, Tongiorgi E, Cattaneo A, Domenici L: Neuronal activity regulates the developmental expression and subcellular localization of cortical BDNF mRNA isoforms in vivo. Mol Cell Neurosci 2005, 28:556-570.

32. Chiaruttini C, Sonego M, Baj G, Simonato M, Tongiorgi E: BDNF mRNA splice variants display activity-dependent targeting to distinct hippocampal laminae. Mol Cell Neurosci 2008, 37:11-19.

33. An JJ, Gharami K, Liao G-Y, Woo NH, Lau AG, Vanevski F, Torre ER, Jones KR, Feng Y, Lu B, Xu B: Distinct role of long 3' UTR BDNF mRNA in spine morphology and synaptic plasticity in hippocampal neurons. Cell 2008, 134:175-187.

34. Liu Q-R, Walther D, Drgon T, Polesskaya O, Lesnick TG, Strain K, de Andrade M, Bower JH, Maraganore DM, Uhl GR: Human brain derived neurotrophic factor (BDNF) genes, splicing patterns, and assessments of associations with substance abuse and Parkinson's Disease. Am J Med Genet B Neuropsychiatr Genet 2005, 134B:93-103.

35. Modarresi F, Faghihi MA, Lopez-Toledano MA, Fatemi RP, Magistri M, Brothers SP, van der Brug MP, Wahlestedt C: Inhibition of natural antisense transcripts in vivo results in gene-specific transcriptional upregulation. Nat Biotechnol 2012, 30:453-459.

36. Phillips HS, Hains JM, Armanini M, Laramee GR, Johnson SA, Winslow JW: BDNF mRNA is decreased in the hippocampus of individuals with Alzheimer's disease. Neuron 1991, 7:695-702.

37. Mogi M, Togari A, Kondo T, Mizuno Y, Komure O, Kuno S, Ichinose $H$, Nagatsu T: Brain-derived growth factor and nerve growth factor concentrations are decreased in the substantia nigra in Parkinson's disease. Neurosci Lett 1999, 270:45-48.

38. Howells DW, Porritt MJ, Wong JY, Batchelor PE, Kalnins R, Hughes AJ, Donnan GA: Reduced BDNF mRNA expression in the Parkinson's disease substantia nigra. Exp Neurol 2000, 166:127-135.

39. Zuccato C, Ciammola A, Rigamonti D, Leavitt BR, Goffredo D, Conti L, MacDonald ME, Friedlander RM, Silani V, Hayden MR, Timmusk T, Sipione S, Cattaneo E: Loss of huntingtin-mediated BDNF gene transcription in Huntington's disease. Science 2001, 293:493-498.

40. Allen SJ, Watson JJ, Shoemark DK, Barua NU, Patel NK: GDNF, NGF and BDNF as therapeutic options for neurodegeneration. Pharmacol Ther 2013, 138:155-175.

41. Zuccato C, Cattaneo E: Brain-derived neurotrophic factor in neurodegenerative diseases. Nat Rev Neurol 2009, 5:311-322. 
42. Chen P-S, Peng G-S, Li G, Yang S, Wu X, Wang C-C, Wilson B, Lu R-B, Gean P-W, Chuang D-M, Hong J-S: Valproate protects dopaminergic neurons in midbrain neuron/glia cultures by stimulating the release of neurotrophic factors from astrocytes. Mol Psychiatry 2006, 11:1116-1125.

43. Zeng Y, Tan M, Kohyama J, Sneddon M, Watson JB, Sun YE, Xie C-W: Epigenetic enhancement of BDNF signaling rescues synaptic plasticity in aging. J Neurosci 2011, 31:17800-17810.

44. Heintz N: BAC to the future: the use of bac transgenic mice for neuroscience research. Nat Rev Neurosci 2001, 2:861-870.

45. Poser I, Sarov M, Hutchins JRA, Hériché J-K, Toyoda Y, Pozniakovsky A, Weigl D, Nitzsche A, Hegemann B, Bird AW, Pelletier L, Kittler R, Hua S, Naumann R, Augsburg M, Sykora MM, Hofemeister H, Zhang Y, Nasmyth K, White KP, Dietzel S, Mechtler K, Durbin R, Stewart AF, Peters J-M, Buchholz F, Hyman AA: BAC TransgeneOmics: a high-throughput method for exploration of protein function in mammals. Nat Methods 2008, 5:409-415.

46. Abranches E, Bekman E, Henrique D: Generation and characterization of a novel mouse embryonic stem cell line with a dynamic reporter of Nanog expression. PLoS One 2013, 8:e59928.

47. Gong S, Zheng C, Doughty ML, Losos K, Didkovsky N, Schambra UB, Nowak NJ, Joyner A, Leblanc G, Hatten ME, Heintz N: A gene expression atlas of the central nervous system based on bacterial artificial chromosomes. Nature 2003, 425:917-925.

48. Smith-Hicks C, Xiao B, Deng R, Ji Y, Zhao X, Shepherd JD, Posern G, Kuhl D, Huganir RL, Ginty DD, Worley PF, Linden DJ: SRF binding to SRE 6.9 in the Arc promoter is essential for LTD in cultured Purkinje cells. Nat Neurosci 2010, 13:1082-1089

49. Li L, Voullaire L, Sandi C, Pook MA, loannou PA, Delatycki MB, Sarsero JP: Pharmacological screening using an FXN-EGFP cellular genomic reporter assay for the therapy of Friedreich ataxia. PLoS One 2013, 8:e55940.

50. Koppel I, Aid-Pavlidis T, Jaanson K, Sepp M, Pruunsild P, Palm K, Timmusk T: Tissue-specific and neural activity-regulated expression of human BDNF gene in BAC transgenic mice. BMC Neurosci 2009, 10:68.

51. Koppel I, Aid-Pavlidis T, Jaanson K, Sepp M, Palm K, Timmusk T: BAC transgenic mice reveal distal Cis-regulatory elements governing BDNF gene expression. Genesis 2010, 48:214-219.

52. Fan F, Wood KV: Bioluminescent assays for high-throughput screening. Assay Drug Dev Technol 2007, 5:127-136.

53. Hong EJ, McCord AE, Greenberg ME: A biological function for the neuronal activity-dependent component of Bdnf transcription in the development of cortical inhibition. Neuron 2008, 60:610-624.

54. Zafra F, Hengerer B, Leibrock J, Thoenen H, Lindholm D: Activity dependent regulation of BDNF and NGF mRNAs in the rat hippocampus is mediated by non-NMDA glutamate receptors. EMBO J 1990, 9:3545-3550.

55. Zafra F, Lindholm D, Castrén E, Hartikka J, Thoenen H: Regulation of brain-derived neurotrophic factor and nerve growth factor mRNA in primary cultures of hippocampal neurons and astrocytes. J Neurosci Off J Soc Neurosci 1992, 12:4793-4799.

56. Koppel I, Timmusk T: Differential regulation of Bdnf expression in cortical neurons by class-selective histone deacetylase inhibitors. Neuropharmacology 2013, 75C:106-115.

57. Calabrese F, Luoni A, Guidotti G, Racagni G, Fumagalli F, Riva MA: Modulation of neuronal plasticity following chronic concomitant administration of the novel antipsychotic lurasidone with the mood stabilizer valproic acid. Psychopharmacology (Berl) 2013, 226:101-112.

58. Fukuchi M, Nii T, Ishimaru N, Minamino A, Hara D, Takasaki I, Tabuchi A, Tsuda M: Valproic acid induces up- or down-regulation of gene expression responsible for the neuronal excitation and inhibition in rat cortical neurons through its epigenetic actions. Neurosci Res 2009, 65:35-43.

59. LV L, Han X, Sun Y, Wang X, Dong Q: Valproic acid improves locomotion in vivo after $\mathrm{SCl}$ and axonal growth of neurons in vitro. Exp Neurol 2012, 233:783-790.

60. Tian F, Hu X-Z, Wu X, Jiang H, Pan H, Marini AM, Lipsky RH: Dynamic chromatin remodeling events in hippocampal neurons are associated with NMDA receptor-mediated activation of Bdnf gene promoter 1 . J Neurochem 2009, 109:1375-1388.

61. Mielcarek M, Benn CL, Franklin SA, Smith DL, Woodman B, Marks PA, Bates GP: SAHA decreases HDAC 2 and 4 levels in vivo and improves molecular phenotypes in the R6/2 mouse model of Huntington's disease. PLoS One 2011, 6:e27746.
62. Barco A, Alarcon JM, Kandel ER: Expression of constitutively active CREB protein facilitates the late phase of long-term potentiation by enhancing synaptic capture. Cell 2002, 108:689-703.

63. Guillemot F, Cerutti I, Auffray C, Devignes M-D: A transgenic mouse model engineered to investigate human brain-derived neurotrophic factor in vivo. Transgenic Res 2007, 16:223-237.

64. Illenye $\mathrm{S}$, Heintz $\mathrm{NH}$ : Functional analysis of bacterial artificial chromosomes in mammalian cells: mouse Cdc6 is associated with the mitotic spindle apparatus. Genomics 2004, 83:66-75.

65. Shimizu N, Miura Y, Sakamoto Y, Tsutsui K: Plasmids with a mammalian replication origin and a matrix attachment region initiate the event similar to gene amplification. Cancer Res 2001, 61:6987-6990.

66. Hahn PJ: Molecular biology of double-minute chromosomes. BioEssays News Rev Mol Cell Dev Biol 1993, 15:477-484

67. Wiener F, Kuschak TI, Ohno S, Mai S: Deregulated expression of c-Myc in a translocation-negative plasmacytoma on extrachromosomal elements that carry lgH and myc genes. Proc Natl Acad Sci U S A 1999, 96:13967-13972.

68. Kuschak TI, Kuschak BC, Smith GM, Wright JA, Mai S: Isolation of extrachromosomal elements by histone immunoprecipitation. Biotechniques 2001, 30:1064-1068. 1070-1072.

69. Wilson RHC, Coverley D: Relationship between DNA replication and the nuclear matrix. Genes Cells 2013, 18:17-31.

70. Frisch M, Frech K, Klingenhoff A, Cartharius K, Liebich I, Werner T: In silico prediction of scaffold/matrix attachment regions in large genomic sequences. Genome Res 2002, 12:349-354.

71. Blaas L, Musteanu M, Eferl R, Bauer A, Casanova E: Bacterial artificial chromosomes improve recombinant protein production in mammalian cells. BMC Biotechnol 2009, 9:3.

72. Wang $Y$, Yu Y, Shabahang S, Wang G, Szalay A: Renilla luciferase-Aequorea GFP (Ruc-GFP) fusion protein, a novel dual reporter for real-time imaging of gene expression in cell cultures and in live animals. Mol Genet Genomics 2002, 268:160-168

73. Corish P, Tyler-Smith C: Attenuation of green fluorescent protein half-life in mammalian cells. Protein Eng 1999, 12:1035-1040.

74. Karpova NN: Role of BDNF epigenetics in activity-dependent neuronal plasticity. Neuropharmacology 2014, 76 Pt C:709-718.

75. Tongiorgi E, Righi M, Cattaneo A: Activity-dependent dendritic targeting of BDNF and TrkB mRNAs in hippocampal neurons. J Neurosci Off J SoC Neurosci 1997, 17:9492-9505.

76. Tongiorgi E, Armellin M, Giulianini PG, Bregola G, Zucchini S, Paradiso B, Steward O, Cattaneo A, Simonato M: Brain-derived neurotrophic factor mRNA and protein are targeted to discrete dendritic laminas by events that trigger epileptogenesis. J Neurosci Off J Soc Neurosci 2004, 24:6842-6852.

77. Poo MM: Neurotrophins as synaptic modulators. Nat Rev Neurosci 2001, 2:24-32.

78. Zafra F, Castrén E, Thoenen H, Lindholm D: Interplay between glutamate and gamma-aminobutyric acid transmitter systems in the physiological regulation of brain-derived neurotrophic factor and nerve growth factor synthesis in hippocampal neurons. Proc Natl Acad Sci U S A 1991, 88:10037-10041.

79. Henegariu O, Heerema NA, Lowe Wright L, Bray-Ward P, Ward DC, Vance GH: Improvements in cytogenetic slide preparation: controlled chromosome spreading, chemical aging and gradual denaturing. Cytometry 2001, 43:101-109.

doi:10.1186/1471-2202-15-75

Cite this article as: Jaanson et al:: BAC-based cellular model for screening regulators of BDNF gene transcription. BMC Neuroscience 2014 15:75. 